\title{
Let Him Use You: Southern Womanism, Utterance, and Saint Katharine Drexel's Educational Philosophy
}

\author{
Berlisha Roketa Morton*
}

* PhD, Independent Researcher, New Orleans, Louisiana, United States Email: berlisha@gmail.com

\section{Article Info}

Received: October 16, 2021

Revised: January 8, 2022

Accepted: January 21, 2022

\subsection{3/jcsr.2022.3}

\section{How to cite}

Morton, B. R. (2022). Let Him Use You: Southern Womanism, Utterance, and Saint Katharine Drexel's Educational Philosophy. Journal of Curriculum Studies Research, 4(1), 1830.

\section{https://doi.org/10.46303/jcsr.2022.3}

\section{Copyright license}

This is an Open Access article distributed under the terms of the Creative Commons Attribution 4.0 International license.

https://creativecommons.org/licenses/by/4.0/

\section{ABSTRACT}

Southern Womanism recognizes the socio-historic ways in which Black women's intellectual subjectivity has been suppressed, and the womanish ways in which their intellectual subjectivity is expressed. Utterance is a complex intersection of art, spirituality, and pedagogy. In this scholarship, Utterance is used as a methodological tool to show how Saint Katharine Drexel worked to develop her educational philosophy alongside her journey in faith and theological and spiritual motherhood. As such, this scholarship continues the lifelong work of Father Cyprian Davis by acknowledging the African roots of Catholicism and the existence of an Afro-Catholic diaspora in which the histories and experiences of Black Catholics are not isolated incidents, whimsical memories, or anecdotal musings. Instead, they are testimonies to the socio-religious agency of the Black Catholic Community. In the Afro-Catholic Diaspora, Saint Katharine Drexel is a beloved witness to the beautiful, mystical, and complex nature of self-determined Black Catholic education intermingled with the magical spirituality of New Orleans, Louisiana.

\section{KEYWORDS}

Black women's studies; Southern womanism; Utterance; Black Catholic education; Black Catholics; Afro-futurism. 


\section{INTRODUCTION}

Just over twenty years have passed since the woman born in Philadelphia, Pennsylvania as Catherine Mary Drexel was canonized in Rome as Saint Katharine Drexel. Drexel scouted locations, purchased land and buildings (often under assumed names), picked out materials, crafted floor plans, and designed buildings for the sole purpose of creating spaces for Black and Indigenous people to self-actualize in ways which honored their ancestral memories, histories, and expressions of Catholicism. For Black Catholics living in communities where Drexel and her Sisters of the Blessed Sacrament built churches and schools, she is known as Mother Katharine. Actually, a simple reference of "Mother" will evoke a communion of warmth among African ascendants in the Afro-Catholic Diaspora. Dillard (2012) uses the term "ascendent" to describe African diasporic people as an upward and forward moving people that are ascending, and not descending, from their ancestral roots (p. ix). This term is deliberately used to describe Black Catholics in the United States because they continue to exist and persist in a country where their contributions to Catholicism have been marginalized to the point of near invisibility. Black Catholics in the United States are not anomalies; they are African ascendents within the AfroCatholic Diaspora.

\section{Purpose}

Outside of the Afro-Catholic diaspora, Mother Katharine's work within Black Catholic communities exists on a two-dimensional plane, with two opposing axes of scholarship which are both rooted in epistemological traditions which unintentionally -- and in some instances, intentionally -- diminish the socio-religious agency of Black Catholics. On one axis, her work with the Black Catholic community is woven into hagiographic narratives of salvation and conversion. In these narratives, she brought Christ to millions of black, unchurched masses upon the collapse of Reconstruction, the beginning of the Jim Crow era and thereafter. On the other axis, she is a paternalistic missionary who imposed the U.S. Catholic Church's Jim Crow policies on Black education in the South.

In their very nature, historical research processes are expressions of collective nostalgia of romanticized, widely accepted institutional narratives. From this perspective, they are limited in their ability to offer solutions to current educational crises. However, this scholarship suggests that approaching historical educational research from a Southern Womanist lens (Morton, 2014; Morton, 2016a.; Morton, 2016b.) can have a direct impact on the field of educational research in general, and education policy in particular. As a theoretical perspective and methodological tool, Southern Womanism continues the life-long work of Father Cyprian Davis by acknowledging the African roots of Catholicism and the existence of an Afro-Catholic diaspora. This scholarship invites readers into the Afro-Catholic Diaspora where the histories and experiences of Black Catholics in the United States are not isolated incidents, whimsical memories, or anecdotal musings. Instead, they are testimonies of the socio-religious agency of the Black Catholic Community. In the Afro-Catholic Diaspora, Mother Katharine is neither hero 
nor villain; she is a beloved witness of the movement for self-determined Black Catholic education. And, as a witness to this self-determination, Mother Katharine experienced a shift from being a missionary to unchurched black souls to becoming an accomplice to the holistic survival of Black people -- mind, body, and spirit.

\section{Theories}

Southern Womanism allows space for spirit within the research process. Space for spirit is particularly important for historical researchers whose intellectual identities have been marginalized in academe. For these researchers, their work is part of a broader process of healing epistemological wounds, unbinding their scholarship from anti-black/anti-feminine epistemologies, and freeing their intellectual ancestors (Morton, 2016b.; Dillard, 2012; Edwards, 2010; Salami, 2020). Blurring the lines between theory and method, Southern Womanism recognizes the socio-historic ways in which Black women's intellectual subjectivity has been suppressed, and the womanish ways in which their intellectual subjectivity is expressed (Morton, 2016b.; Morton, 2016a.). To access this knowledge, the research process must be reimagined as an onto-epistemological space where the subjectivity of the Black Divine Feminine can be accessed through with methods associated with Afrofuturism and through the writings of authors of the Black Southern Renaissance -- Jesmyn Ward (2017), Kiese Laymon (2018), Eddie S. Glaude, Jr., (2020), Regina N. Bradley (2021), Tressie McMillan Cottom (2021).

Southern Womanism gives researchers a process to free themselves from collective nostalgia, and essentially, free their intellectual ancestors from the bondage of being framed in pictures where they are gazed upon as mere historical objectives. Southern Womanism understands that to see beyond the framed picture, researchers must look at their history with their soul. When the soul is allowed to look beyond the frame, the mind is then compelled to search for the intellectual wisdom of its ancestors in a dance of reason and spirit. Kiese Laymon explained this phenomena on Darnell Moore's podcast Being Seen when he said, "Sometimes, we gotta get out of the super structure and down to the narrow, and we cannot get anymore narrow than the specificity of the body... think we have to let all this lush theory guide us back to the origin, and then let the origin magnify and broaden the theory" (Moore, 2020). In this sense, our bodies become archives -- living sites of ancestral memory. And in this living archive, Utterance is the grace which allows Southern Womanism to blur the lines between theory and method. Utterance makes what is tangible in the supernatural realm of the Black Southern Divine Feminine apparent to those who want to be invited in (Moore, 2018) to the material world of justice work.

Utterance is a complex intersection of art, spirituality, and pedagogy (Morton, 2016a., p. 750). Utterance is an onto-epistemological process in which spiritual wisdom morphed into selfprotective phrases used by Black enslaved and domestic women to protect themselves from the egregious emotional, mental, physical, and sexual violence they experienced in their homes and workplaces (p. 750). In this sense, phrases such as, 'you can't see for lookin' and 'ima feed him 
with a long-handled spoon,' become lusher than folk knowledge; they are the theoretical underpinnings of phenomenological experiences for people who find themselves in southernized spaces -- i.e., spaces of hostile collective nostalgia, gross educational disinvestment, sanctioned resource scarcity, and fervent religiosity.

Southern Womanism and Utterance allows for a more complex and nuanced exploration of Mother Katherine's work in Black Catholic education because in acknowledging the AfroCatholic diaspora, it also acknowledges the presence of Black Feminine Divinity within the diaspora. Mainstream studies of Black Catholicism and hence, Black Catholic education are overwhelmingly written from male perspectives which focus on racist patriarchal, hierarchical structures which have served as a hindrance for Black men ascending the ranks of the Church hierarchy -- priest, bishop, archbishop, cardinal, pope (Davis, 1990; Davis and Pope-Davis 2017; MacGregor, 1999; Ochs, 1990; Phelps, 1997). Similarly, studies written from a feminist post structural analysis turn Mother Katharine into an outsider within Church structure, and the schools and churches she funded become trophies to her successful manipulation of Church hierarchy (Morton, 2013). As such, the current literature on Black Catholic education in the South is woefully stuck in a frame of a collective nostalgia with a myopic focus on the forever struggle for Black Catholics to be seen and supported by the U.S. Church (Collopy, 2011). These studies are valuable because they provide the foundation for research on Black Catholic education in the South. But when these studies become the sole source of Black Catholic literature, the full depth and breadth of the complex nature of Black Catholic education cannot be fully interrogated because they glaze over and magnify the Church's existential crisis of the role of women in the Church. And thereby, ignores the Church's African cosmological roots which includes the presence of Black Feminine Divinity.

\section{METHODS}

Southern Womanism uses Utterance to make the intangible presence of Black Feminine Divinity apparent in Black Catholic education in the South. When told through Utterance, Mother Katherine's life becomes a living archive of tactics and strategies for the advocation of Black education in general, and Black Catholic education in particular. Therefore, inquiries as to whether Mother Katharine's actions were motivated by paternalism, and racism are irrelevant. What is more valuable for today's educational landscape is the Morrisonian question of not why, but how Mother's existential shift allowed her to move from the space of a missionary to embodying the role of an accomplice to the creation of an educational system that expresses the African roots of Catholicism. As such, this scholarship does not try to hide or explain away moments in Mother Katharine's history that are perceived as racist or paternal. These moments are part of the white ally's experience when they, like Mother Katharine, are indoctrinated into social justice ideologies rooted in liberal deficit theories of Black education.

When Utterance is used as a methodological tool, moments in Mother Katherine's life -known and not so known -- show the work Mother Katharine did to develop her educational 
philosophy alongside her journey in faith and theological and spiritual motherhood. While these pages do not offer the space to explore the entirety of Mother Katherine's history, Utterance reveals the most well-known moments in Saint Katherine Drexel lore as an expression of the beautiful, mystical, and complex nature of Black Catholic education intermingled with the magical spirituality of New Orleans, Louisiana.

\section{RESULTS}

Before she was Mother Mary Katherine Drexel, she was Catherine Mary Drexel, a grieving woman looking for her beloved parents in the daylight with a candle. You're gonna be lookin' for me with a candle in the daylight when I'm gone is an utterance that expresses the temporality of life and the ways in which we take our loved ones' physical presence for granted. This utterance is a warning that essentially says, "you cannot even comprehend just how much you're going to miss me and all things I do when I am no longer on this earth." This utterance is intended to evoke feelings of grief and sadness in the hearer because it visualizes an inconsolable and illogical depth of grief in believing that the light given off by a candle can compete with sunlight. But that little bit of light represents the sad hope that maybe in that little bit of extra light, we can see our loved one just one more time.

Upon their parent's untimely deaths, the Drexel sisters' grief, and willingness to give freely of themselves and their fortune coincided with the U.S. Catholic Church's existential crisis of following Rome's directives against bigotry and racism while fighting American antiCatholicism by embracing American bigotry (Collopy, 2011). Drexel's transformation from Catherine, the heiress, to Katharine, the Mother, was not a clean break. Despite all the machinations she used to separate herself from personally benefiting materially from her wealth, she was still a white woman born of wealth and privilege. Specifically, she was a wealthy, white Northeastern Catholic ensconced in the ethos of Catholic social justice dogma.

As devout Catholics with considerable wealth, the utterance, charity begins at home and spreads abroad was a way of being and knowing for the Drexel family. Because of their fortune and influence, the Drexel family were members of the emerging super-wealthy class of the late $19^{\text {th }}$ and early $20^{\text {th }}$ centuries (Morton, 2014). Collopy's detailed history of the American Church's early history illuminates how impactful the Holy See's writings and directives on missions for people of color would have been for the devout and grieving Drexel sisters' intent on honoring their parents through charitable giving. They answered Rome's call for missionaries to first "evangelize African Americans...rescue them from the darkness of sin" and second "to improve their social lot" (Collopy, 2011, p. 19). It is in this space that the utterance, charity begins at home and spread abroad becomes complex.

In Southern Womanism, charity is defined as kindness to one's fellow family members which in turn translates to kindness to the human family. Charity is understanding that one only survives because of God's grace and mercy; and to truly be like Christ, we give to others from the overflow of grace and mercy in our lives. Charity is not a financial gift; it is a gift of love when 
all one has to give is love. And that love is evidence of the Living Christ. Hence, we freely give charity because family extends beyond the household, and community extends beyond the neighborhood (Morton, 2016b.).

Although she was not formally educated, Mother Katharine was a highly learned woman, and as a devout Catholic, she would have read and internalized the Holy See's written directives for missionary zeal. She was a woman of her time and understood her place in the hierarchy and was devoted to her place in the hierarchy. In her early years as a Mother of a religious order, Mother Katherine was mentored by bishops and powerful laymen of the American Church and Markmann (2012) explains that these men's tutelage were beyond influential; it was apostolic beyond question. Mother Katharine existed in this space where she performed intentional philanthropy safely ensconced in the hierarchical patriarchy; that is until the community she was sent on a mission to save made her question the mission.

Mother Katharine was not completely naïve to the delicate threads that connected race, religion, and education as she specifically chose to do the Church's work with Black and Indigenous people (Morton, 2014). However, it was not until she entered New Orleans that she began to see that these threads were not woven in black and white (Morton, 2014). And more importantly, she began to question exactly what she was spreading abroad. And she learns, the hard way, the meaning of the utterance, what you don't know will make a whole new world. It is a blunt chastisement that lets the hearer know, "not only do you not know as much as you think you know, actually, you don't know anything."

Afro-Catholics in New Orleans lived in a world of their own making, and they were fiercely protective of their world. The end of the nineteenth century saw Afro-Catholics in New Orleans in a bitter fight against the imposition of an Americanized system of segregation which reduced the public rights of New Orleanians of color. It was in this environment that New Orleans Archbishop Francis A. Janssens invited Mother Katharine to fund St. Katharine's, the first "negro only" parish (church) in New Orleans (Morton, 2014). And of course, Mother Katharine answered the invitation with verve. As to whether or not Janssens's intentions were deliberately, his actions were in line with the American Church's acquiescence to the Jim Crow policies being enacted in the South (Morton, 2013; Morton, 2014). Afro-Catholics in New Orleans harshly and publicly criticized Mother Katharine for being a co-conspirator in the Church's attempt to solve its "negro problem" by enforcing segregation (Morton, 2014). Prominent Afro-Catholic leader Rudolph L. Desdunes eloquently summarized the inherent flaw in her actions in relation to Catholic theology in a column for The Daily Crusader

Mother Katherine has taken the vows of the church, and yet she seems by her actions unconsciously to drift into the channels which lead into errors and contradictions. While Christ has established the Father-hood [sic] of God and the Brotherhood of man, the great Mother's benevolence is being used by destination to destroy the fundamental principle of our religion. If men are divided by, or in, the Church, where can they be 
united in the bonds of faith and love of truth and justice? (Desdunes, 1895, Xavier University Archives)

This criticism was personally devastating and unsettling for Mother Katharine because it caused her to question the needs of the souls under her purview versus the needs of the hierarchy. Writing in 1966, Sister Consuela Marie Duffy of the Sisters of the Blessed Sacrament relayed a reflection from Drexel's personal notebook in which she wrote, "It seems that on Sundays, the Colored prefer to go to Church with the Whites" (p. 314). This is often the sentence that scholars select to present Mother Katharine's position on the situation; however, Mother's next written lines are also essential: "Before Archbishop Janssens purchased St. Katharine's, the Colored asked for a separate Church. They retracted but he held them to this first demand" ( $p$. 314). Duffy (1966) analyzes Mother Katharine's writing as follows

We do not have any other evidence of this request made by some of the Colored people themselves for a separate church, but a woman as exact and painstaking as Mother $\mathrm{M}$. Katharine would never have written this unless she had definite facts to justify it. (p. 314) In Saint Katharine Drexel lore, this moment is seen as a faux pas, evidence of the sins regular people encounter on the path to Sainthood. However, from a Southern Womanist perspective, a shift in Mother Katharine's understanding of her work is visible. She begins to understand that the Drexel money was indispensable to the Church's work, but her body was dispensable. And just as her body was dispensable, so too were the bodies which contained the souls she was charged to save. In the twenty-year period between her first invitation to save souls in New Orleans to her opening of Xavier University, she begins to understand that real systemic change can only occur through experiencing collective empathy. Collective empathy cannot live in blissful cosmetic collective nostalgia; it is only gained by working with community members and experiencing, together, the sweat of fear, the weariness of battle, the sting of antiseptic on wounds, the itchiness of healing, and the grace to get up, yet again, to make a way out of no way. At this moment, stories begin to be documented of Mother Katherine hiring watchmen to protect the communities where she was building and fighting off the Klu Klux Klan (Markmann, 2012; Morton, 2013). But more importantly, she begins to understand the true value of her white privilege intermingled with the invisibility of a woman in a nun's habit.

Essentially, Mother Katharine's greatest asset was her white privilege - her lawyers, her business acumen, her money, her knowledge of banking and real estate, and her knowledge of intentional philanthropy. She used her privilege, and the inattentional blindness the Church and society had toward women to create a new supernatural technology to subvert racist systems to create safe spaces for people of color to learn and worship. In this sense, the utterance, you can't see for lookin' becomes a tactic Mother Katharine uses to lay the groundwork for the foundation of Xavier University in New Orleans.

You can't see for lookin' refers to how Black women's work is often disturbed (Morton, 2016a.) by people's inability to find things on their own. This inattentional blindness becomes a way of life for people who are not forced to look beyond their own needs while Black women 
must always see, and attend to, the needs of everyone around them. Mother Katharine inverted this tactic to inconspicuously visit the Old Southern University buildings she wanted to purchase for Xavier University without setting off alarm bells that the nun famous for building schools for Black people was wandering around the Uptown neighborhood -- a neighborhood that white New Orleanians had decided to claim as their own. This tactic worked, and Mother Katharine relayed their success in a letter to the Sisters at the Motherhouse in Pennsylvania

We went to see the Southern University as soon as we had received Holy Communion and breakfasted...The member of the board who was in an office to the right, to our inquiry as to whether we could look around, said, "Yes" in an indifferent kind of way, and he let us go around by ourselves and apparently forgot all about us. (Drexel, 1915, Xavier University Archives)

The sale of the old Southern University physical plant was finalized on August 14, 1915 (Notarial Archives, New Orleans, Louisiana, Act 00032). In the Sisters of the Blessed Sacrament convent annals from New Orleans, the Sisters wrote of their first months in New Orleans as well as the first months of what they referred to as the "reopening of Southern University." In the early months of September 1915, they wrote;

The colored people are so delighted to have Southern back again that they are doing everything to help us. We have received a list of probable students and September 9th has been selected for 'visitation day'. The Sisters will visit these homes even tho [sic] they are strangers in a strange land. (Sisters of the Blessed Sacrament, 1915b., p. 4)

As she was in New Orleans during this time, Mother Katharine would have been among the Sisters walking the streets and visiting homes in the city (Morton, 2014). Upon their return, the convent annalist wrote;

The Sisters were well received in every home and they found the people most refined and seemingly in better circumstances than the colored in the North. We have every reason to believe that we shall have a good attendance as the newspapers have given us splendid write-ups. Mother is praying for at least two hundred children, boys too, but only manageable boys. On all sides we hear, 'You will have plenty scholars'. We are trusting to the Lord that this will be the case. (Sisters of the Blessed Sacrament, 1915b, p. 4)

The Sisters opened Xavier University on September 27, 1915. The scholars came, and several of the classrooms were overcrowded (Morton,2014). In June 1915, three separate commencement programs were held, and according to the convent annals, "all the exercises were attended" (Sisters of the Blessed Sacrament, 1915b., p. 21). The first program, the Baccalaureate service, took place on June 11, 1916, at 8pm. According to the Morning Star, Reverend Carl F. Schappert, S.S. J., preached the sermon "before a most appreciative audience" (p. 21). On June 15, 1916, forty-six eighth grade students received certificates "entitling them to enter the High School Department next fall" (p. 21). At the June 16, 1916, commencement exercise, five students received diplomas from the evening normal class: Mr. George Carpenter, 
Miss Beatrice Bell, Zerita Bell, Evelyn LaChappelle and Mrs. Pricilla Waterhouse. Of this ceremony the convent annalist noted

[T] he auditorium was packed to capacity in spite of the fact that there was a very heavy rain. We had to send many away and close the doors at eight o'clock. The rain was so heavy that we had to open a few classrooms to give shelter to those who could not be accommodated in the auditorium. (p. 22)

The Sisters dedicated these words at the end of the 1915 Old Southern Year Book;

We hope the story of our work at "Old Southern" may be found written at the hearthstone of thousands of families throughout the length and breadth of New Orleans. We hope the story of our work shall be burned into the very lives of devoted Catholic and non-Catholic, who trained within the walls of 'Old Southern,' shall do their share toward maintaining and perpetuating its holy ideals; and who shall yet offer the tribute of their love to the nuns who trained them in the ways that lead to life. Very respectfully yours, The Sisters of the Blessed Sacrament (Sisters of the Blessed Sacrament, 1915a., Xavier University Archives).

\section{DISCUSSION}

A key tenet of Catholic education is Universality. Black protestants and non-church going Black folks attended and continue to attend Black Catholic schools in general, and Xavier University in particular. In an evocation of Mother Katharine's prayers for justice, Christopher Parris, Sr., quoted the Leadership of the National Black Sisters Conference on a Facebook post: "Education and Religion are the first two subversive forces that an oppressed people can use to free themselves. Religion is the guts of all human life, it can suppress a people or free a nation" (National Black Sisters Conference, 2021). When Mother Katharine opened schools for Black Americans in New Orleans, she activated a mystical process. New Orleans itself is a metaphysical text. The city is thick with African history, African cosmology, Southern Gothicism, and Black Feminine Divinity. It is not an accident that Xavier University, the first and only Black Catholic institution in the United States, is in New Orleans, Louisiana. In Philadelphia, Mother Katharine is encased in stone and Xavier University is the jewel of Mother Katharine's legacy. However, in New Orleans, Xavier is alive; and Mother Katharine lives through her educational philosophy. In Philadelphia, the figures of color encased in beautiful shrines to Mother Kathrine are alive in New Orleans; they are living archives of love; they love Mother Katharine because they know she sweated with their ancestors. And their combined sweat watered the spirit of the AfroCatholic Diaspora. Verily, there would be no Xavier University without Mother Katharine Drexel; and there would be no Saint Katharine Drexel without New Orleans. It is in New Orleans that Mother Katharine experienced firsthand the problematic nature of the Church hierarchy; and it is in New Orleans where she saw beyond hierarchy, and looked with soul into the beauty of Blackness and saw Black Joy. The historical line from the Mother's rescuing of the space that became Xavier University which continues to the space that educates young black women is not sad, but joyful. In the utterance, they didn't give us our joy, so they can't take it, "they" 
refers to white supremacists, sexists, predators, etc. as being no match for the sustainability of Black Joy. Black Joy is metaphysical and the material expression of survival.

Let Him Use You is an utterance used in Black religious spaces where someone overcome with Black Joy allows God to take over their spirit so they can testify to God's omnipotence, omniscience, and omnipresence. The primary criticism of Drexel's educational philosophy was her belief in divine providence (Morton, 2014). Her father's last will and testament stipulated that if no heirs were ever born to his three daughters, upon the last daughter's death, the estate funds would be distributed to charity (Morton, 2014). When Francis Drexel died suddenly, he could not have anticipated Catherine would become Mother Mary Katharine, founder of Xavier University, the centerpiece of a system for Black Catholic education from pre-school to professional school. Fear of the financial sustainability of this system without Drexel money induced calls for Mother Katharine to break her father's will; yet she did not do it. She truly believed that God would provide for the communities upon her death.

When Xavier Prep, a high school for young Catholic women which exists the original grounds of Xavier University almost closed in 2013, many saw it as evidence that Mother made a grave mistake in not breaking the will. But Xavier Prep did not close; it was reopened as St. Katharine Drexel Preparatory High School. The school's survival is evidence that if you Let Him Use You, God will provide. Mother's faithfulness provides a valuable lesson of her educational philosophy. Mother believed that the people were Church, the material manifestation of the Mystical Body of Christ. The closing of the Motherhouse in Philadelphia and the closing of churches and schools she founded are not markers of Mother's mistake; instead, they are indicators of Church faithful's misunderstanding of the theology of Mother's educational philosophy. Instead of questioning Mother's decision to not break her father's will, those interested in the survival of Black Catholic education should be asking themselves, are you letting Him use you?

Mother Katharine was a witness to a people whose love for education was rooted in spiritual expressions of Black Joy. The love Black Catholics have for Mother Katharine is witness to this supernatural love. The exchange of love between the Afro-Catholic Diaspora and the woman they call Mother is physically palpable in New Orleans on Xavier's campus. She saw Black Joy, and she made the rest of the world see Black Joy, and she continues to make the world see Black Joy.

On April 4, 1968, the Sisters of the Blessed Sacrament appointed Dr. Norman C. Francis the Xavier University's first Black and lay president (Morton, 2014). Dr. Francis, who led Xavier University for almost fifty years, has been credited with shaping the policies that have allowed Xavier to have long term success in preparing its Black graduates for medical school and its graduate programs in science, specifically its School of Pharmacy (Morton, 2014). Dr. Francis has also been credited with leading the university to a strong reopening in the aftermath of Hurricane Katrina. He retired as the longest serving university president in the United States and is a recipient of the Presidential Medal of Freedom. In January of 2021 the roadway that Xavier 
University overlooks, named Jefferson Davis Parkway, was renamed Norman C. Francis Parkway. When Dr. Francis cut the ribbon on Norman C. Francis Parkway, he brought joy to all people with a signal of change, hope, and love. Ascendents of the Afro-Catholic successfully petitioned for this change because they can't take our joy.

\section{CONCLUSION}

Southern Womanism and Utterance allows Mother Katherine's educational philosophy to emerge -Total Gift of Self, Providing the Best for the Most Vulnerable, a Belief in Divine Providence, Courageous Travel, and Understanding Death as Life (Morton, 2014). The concept of the total gift of self is heavily present in Mother Katharine's journey to sainthood. When the Drexel family engaged in school building projects for women, Black and Indigenous people in the late $19^{\text {th }}$ and early $20^{\text {th }}$ centuries, they were motivated by the Catholic principles of Universalism. Eventually, this morphed into a cosmopolitan philosophy of education where belief in divine providence became as equally important as courageous travel. In her life as a debutante and a missionary, Mother Katharine constantly travelled. It is during travel that Mother Katharine documented best practices in architecture which led her to always strive to provide for the best for the most vulnerable students at her schools. The primary criticism of Drexel's educational philosophy was her belief in divine providence. To be clear, this belief came from an understanding of life as death. Death was ever present in Mother Katharine's life beginning with the death of her biological mother as an infant, to the deaths of Francis, Emma, and Elizabeth when she was a young woman and later in life with the deaths of her travel companion and assistant, Mother M. Mercedes, and her beloved sister, Louise Drexel Morrell. But as a courageous traveler, in a spiritual and physical sense, Mother Katharine always confronted death and believed that life could flourish from death, within death, and despite death. As Jim Crow tried to bring death to the educational dreams of Black people, she instead saw Black Joy, and fought for spaces for Black Joy to flourish.

Mother Katharine's journey is a road map to the bumps and bruises that are bound to happen in the fight for educational equity. Mother Katharine faced the same challenges which continue to persist in education - segregation, underfunding, undereducation, racism, sexism, abuse, and mass incarceration. To those who want to get invited in to do the work, be prepared to work like Mother worked, sweat like Mother sweated, and love like Mother loved.

\section{REFERENCES}

Bradley, R. N. (2021). Chronicling Stankonia: The Rise of the Hip-Hop South. The University of North Carolina Press.

Collopy, W. F. (2011). Welfare and Conversion: The Catholic Church in African American Communities in the U.S. South, 1884-1939 [PhD diss]. Texas A\&M University.

Cottom, T. M. (2021, February 24). The Dolly Moment. essaying.

https://tressie.substack.com/p/the-dolly-moment 
Davis, C. (1990). The History of Black Catholics in the United States. The Crossroad Publishing Company.

Davis, D. W., \& Pope-Davis, D. B. (2017). Perseverance in the Parish? Religious Attitudes from a Black Catholic Perspective. Cambridge University Press.

Desdunes, R. L. (1895, February 28). Mother Katharine Drexel and the Color Line [Column for The Daily Crusader]. In Crusader Clippings Collection box, document number $1 / 24$. The Daily Crusader.

Dillard, C. B. (2012). Learning to (Re)member the Things We've Learned to Forget: Endarkened Feminisims, Spirituality, \& the Sacred Nature of Research \& Teaching. Peter Lang.

Drexel, M. M. K. (1915). Letter to Sisters of the Blessed Sacrament [Correspondence]. In Louisiana Corporation Folder. Xavier University Archives, New Orleans, Louisiana.

Duffy, C. M. (1966). Katharine Drexel: A Biography. The Peter Reilly Company.

Edwards, K. T. (2010, October). Incidents in the Life of Kirsten T. Edwards: A Personal Examination of the Academic In-between Space. Journal of Curriculum Theorizing, 26(1), 113-128. 1942-2563

Glaude. Jr., E. S. (2020). Begin Again: James Baldwin's America and It's Urgent Lessons for Our Own. Crown.

Laymon, K. (2018). Heavy. Scribner.

MacGregor, M. J. (1999). The Emergence of a Black Catholic Community: St. Augustine's in Washington. The Catholic University of America Press.

Markmann, M. M. (2012). Katharine Drexel: Educational Reform and Institution Builder [PhD diss]. Temple University.

Moore, D. L. (Director). (2020). Being Seen (K. Laymon, Performer) (Season 1, Episode 05) [TV series episode]. In Creating Context. Retrieved November 11, 2020, from https://www.beingseenpodcast.com/season-1

Moore, D. N. (2018). No Ashes in the Fire: Coming of Age Black \& Free in America. Nation Books.

Morton, B. (2013, November). History as Death and Living Ghosts: The Mislaid Memories of Saint Katharine Drexel. Journal of Curriculum Theorizing, 1(29), 117-133. 1942-2563

Morton, B. (2014). With Xavier, however, there will be this distinction: Mapping the Educational Philosophy of Saint Katharine Drexel in the Intellectual Tradition of Black Catholic Higher Education in New Orleans [PhD diss]. Louisiana State University.

Morton, B. (2016a.). Ain't Nothin' Wrong with Cleanin' Houses: Utterances on Southern Womanism and the Search for Our Mamas' Garden. In D. T. Baszile, K. T. Edwards, \& N. A. Guillory (Eds.), Race, Gender, and Curriculum Theorizing: Working in Womanish Ways (pp. 17-36). Lexington Books.

Morton, B. (2016b., August). 'You can't see for lookin": how southern womanism informs perspectives of work and curriculum theory. Gender and Education, 28(6), 742-755. http://dx.doi.org/10.1080/09540253.2016.1221897 
National Black Sisters Conference. (2021). Philanthropy Like - Catherine.

Ochs, S. J. (1990). Desegregating the Altar. Louisiana State University Press.

Phelps, J. T. (1997). Black and Catholic, The Challenge and Gift of Black Folk: Contributions of African American Experience and Thought to Catholic Theology. Marquette University Press.

Salami, M. (2020). Sensuous Knowledge: A Black Feminist Approach for Everyone. Amistad.

Sisters of the Blessed Sacrament. (1915a). Old Southern Yearbook. Xavier University Archives, New Orleans, Louisiana.

Sisters of the Blessed Sacrament. (1915b). SBS Convent Annals. Xavier University Archives, New Orleans, Louisiana.

Ward, J. (2017). Sing, Unburied, Sing. Scribner. 